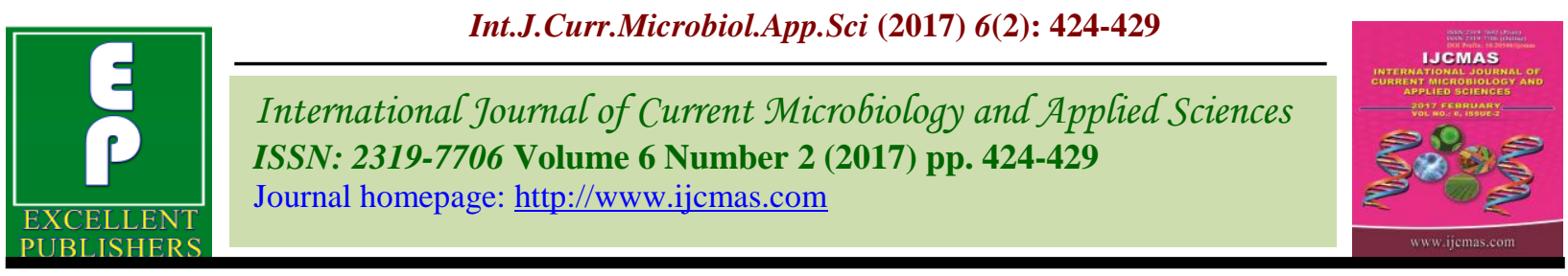

Original Research Article

http://dx.doi.org/10.20546/ijcmas.2017.602.047

\title{
Genetic Diversity Studies in Desmodium gangeticum (L.) DC.
}

\author{
H.R. Nandanwar ${ }^{1}$, P. Manivel ${ }^{2}$, A.S. Patil ${ }^{1}$, A.A. Punewar ${ }^{1}$ and R. Saravanan ${ }^{2}$ \\ ${ }^{1}$ Department of Plant Breeding and Genetics, Anand Agricultural University, \\ Anand (388 110), Gujarat, India \\ ${ }^{2}$ Directorate of Medicinal and Aromatic Plants Research (DMAPR), \\ Boriavi, Anand (387 310), Gujarat, India \\ *Corresponding author
}

\section{A B S T R A C T}

\begin{abstract}
Keywords
Thirty Desmodium gangeticum (L.) DC. accessions were evaluated for genetic variability, heritability and genetic advance for four yield attributing traits collected from different parts of India. The analysis of variance for mean squares for different characters was found

Desmodium gangeticum,

Heritability,

Genetic advance,

Coefficient of

variation.

Article Info to be highly significant for most of the characters under study except for lamina width, petiole length and internode length. Parameters of variability studies such as genotypic coefficient of variation, phenotypic coefficient of variation, heritability (broad sense) and expected genetic advance over mean were calculated and the data indicated that ample amount of variability exists in the available germplasm lines. High genotypic coefficient of variation was exhibited by pod fresh weight $(70.24 \%)$, stem fresh weight $(67.68 \%)$, leaf fresh weight $(67.34 \%)$, stem dry weight $(66.92 \%)$ and leaf dry weight $(64.24 \%)$. Higher heritability was recorded by various characters like plant height $(93.12 \%)$, tip height Accepted: 15 January 2017 Available Online: 10 February 2017 $(85.65 \%)$, root girth $(84.54 \%)$, stem girth $(84.15 \%)$ and pod fresh weight $(78.21 \%)$. High genetic advance was recorded in stem fresh weight $(15.77 \%)$, stem dry weight $(15.66 \%)$, leaf fresh weight $(15.36 \%)$, leaf dry weight $(14.75 \%)$ and tip height $(14.03 \%)$. Thus, these germplasm lines could be utilized to improve root fresh weight, root dry weight and related characters in future breeding programme.
\end{abstract}

\section{Introduction}

Desmodium is a genus in the flowering plant family Fabaceae, which is sometimes also called as tick-trefoil, tick clover or beggar lice. Desmodium is a perennial or annual herbs or shrubs found throughout tropical and subtropical regions (Chopra et al., 1956). About 38 species of Desmodium occur in India, of which several are considered medicinally important (Chopra et al., 1956; Nadkarni, 1976). Among the medicinal species of Desmodium, Desmodium gangeticum (L.) DC also commonly referred as Shalaparni is one of the most valued of ten drugs that constitutes the ayurvedic preparation 'dasamoola'. Besides dasamoolarishta, this species is used in the composition of several important ayurvedic formulations such aschyavanaprasam and dhanvantharamtailam. D. gangeticum (L.) DC is an effective cardio tonic with diuretic and laxative actions. It is employed as a nervine tonic (Kirtikar and Basu, 1975). It is effective in overcoming burning sensation, fever, dysentery, thirst and vomiting and calms difficulty in breathing. It is also effective in curing hazy vision. Roots are mainly used in 
ayurvedic preparations which contain the pterocarpenoids, gangetin, gangetinin and desmodin. Roots have antipyretic, expectorant, alterative and diuretic properties. Aerial parts contain tryptamine derivatives. The alkaloids from aerial parts have hypotensive and anticholinesterase activity and act as stimulant of central nervous system (Iwu et al., 1992).

The variability in plant population is the prerequisite for improvement in any breeding programme (Kumar et al., 2013). A detailed understanding of genetic variability and other related parameters like heritability and genetic advance are important to study yield and yield attributing characters. The yield being a complex character with low heritability is influenced by number of factors inherent both in plant as well as in the environment in which plant grows. Therefore, selection for such characters based on phenotypic expression is likely to be less efficient. Under such circumstances, the breeder has to modify the direction of selection considering the relative influence of different yield contributing characters on yield. The knowledge of association among the different components of yield is crucial for designing an effective plant breeding programme through selection and for simultaneous improvement of yield components. Therefore, such information can be obtained from genotypic and phenotypic correlation coefficients between yield and yield contributing characters (Singh, 2005). Therefore, the proposed study aims to utilize the existing germplasm lines to improve root fresh weight, root dry weight and related characters in future breeding programme.

\section{Materials and Methods}

The material used for the present study comprised of 30 germplasm accessions of $D$. gangeticum (L.) DC. collected from different states of India such as Gujarat, Kerala, Rajasthan, Andhra Pradesh and Tamil Nadu through forest explorations. The present study on genetic variability in D. gangeticum (L.) DC. was carried out during late kharif2009 to 2011 at the Directorate of Medicinal and Aromatic Plants Research (DMAPR), Indian Council of Agricultural Research (ICAR), Boriavi, Anand. The research institute lies in latitude of $22.5^{\circ}$ and longitude $73.0^{\circ}$ and has average rainfall $800 \mathrm{~mm}$, maximum and minimum temperature ranges between $42^{\circ}$ to $12.7^{\circ}$ C. The experimental design was randomised complete block design with three replications and 30 germplasm lines as treatments. Plot size was single row of 6 meter length with spacing of $45 \times 45 \mathrm{~cm}^{2}$. The magnitudes of GCV, PCV, heritability and expected genetic advance were estimated by formula given by Burton (1952). The observations were recorded for plant height $(\mathrm{cm})$, tip height $(\mathrm{cm})$, stem girth $(\mathrm{mm})$, root girth $(\mathrm{mm})$, root height $(\mathrm{cm})$, root branch, number of primary branches (PB) plant ${ }^{-1}$, number of secondary branches (SB) plant $^{-1}$, number of leaves plant $^{-1}$, number of inflorescence plant ${ }^{-1}$, length of inflorescence, number of inflorescence plant ${ }^{-1}$, length of inflorescence, plant weight $(\mathrm{g})$, root fresh weight plant $^{-1}(\mathrm{~g})$, root dry weight plant ${ }^{-1}(\mathrm{~g})$, stem fresh weight plant ${ }^{-1}(\mathrm{~g})$, stem dry weight plant $^{-1}(\mathrm{~g})$, leaf fresh weight plant $^{-1}(\mathrm{~g})$, leaf dry weight plant $^{-1}(\mathrm{~g})$, leaf area plant ${ }^{-1}\left(\mathrm{~cm}^{2}\right)$, pod fresh weight plant $^{-1}(\mathrm{~g})$, lamina width $(\mathrm{cm})$, lamina length $(\mathrm{cm})$,petiole length $(\mathrm{cm})$ and internode length $(\mathrm{cm})$.

\section{Results and Discussion}

The magnitude of genetic variability present in the germplasm determines the success of the breeding program for crop improvement. It is important to maintain variability in the population in order to bring the genetic improvement in the characters of economic importance. Variability in the population can 
only be introduced by using genetically diverse germplasm lines. It is also important to assess the existing genetic variability in the material in order to exploit it for crop improvement (Sharma et al., 2014). In the present study, the variability parameters like genotypic coefficients of variation (GCV), phenotypic coefficient of variation (PCV), heritability estimates in broad sense $\left(h^{2}\right)$ and expected genetic advance were estimated for 24 characters and results obtained have been presented in table 1 and 2 discussed as under.

\section{Analysis of variance for different characters}

The analysis of variance for mean squares for different characters was found to be highly significant for all the characters under study except for lamina width, petiole length and internode length. The data indicated that ample amount of variability exists in the germplasm lines. The ANOVA for different characters are presented in table 1 .

\section{Components of variances}

The GCV, PCV, heritability and expected genetic advance was estimated by formula given by Burton (1952). The genotypic coefficient of variation, heritability (broad sense) and expected genetic advance over mean are presented in table 2.

\section{Genotypic coefficient of variation (GCV)}

The data for 24 different characters was subjected to statistical analysis for genetic variability and genotypic coefficient of variation was estimated, which ranged from $17.10 \%$ (internode and petiole length) to $70.24 \%$ (pod fresh weight). Moderate to high genotypic coefficient of variation was exhibited by stem fresh weight (67.68\%), leaf fresh weight (67.34\%), stem dry weight $(66.92 \%)$, leaf dry weight $(64.24 \%)$, tip height (50.12\%), number of inflorescence $(49.60 \%)$, root dry weight $(49.44 \%)$, plant height $(48.90 \%)$ and root fresh weight $(45.62 \%)$.The characters lamina length, root height, length of inflorescence, lamina width and root girth recorded comparatively low GCV values.

\section{Phenotypic coefficient of variation (PCV)}

The magnitude of phenotypic coefficient of variation was higher than genotypic coefficient of variation for all the characters under study. Maximum phenotypic coefficient of variation was exhibited by number of inflorescence i.e. 90.21\% while lowest PCV value was observed in petiole length (19.80\%). High PCV values were recorded by leaf fresh weight $(81.55 \%)$ followed by leaf dry weight (80.22\%), pod fresh weight (79.42\%), stem fresh weight $(78.18 \%)$ and stem dry weight (77.52\%). Moderate magnitude of phenotypic coefficient of variation expressed by plant weight $(63.53 \%)$, root dry weight $(60.94 \%)$, root fresh weight $(60.51 \%)$, number of leaves $(56.48 \%)$, tip height $(54.16 \%)$ and secondary branches $(50.36 \%)$, while root height, lamina length, lamina width, length of inflorescence, root girth and internode length exhibited comparatively low PCV values.

\section{Heritability $\left(\mathbf{h}^{2}\right)$}

Broad sense heritability was estimated from GCV and PCV values. It is observed that heritability ranged from $30.23 \%$ for number of inflorescence to $96.03 \%$ for leaf area. High heritability was recorded by plant height $(93.12 \%)$, tip height $(85.65 \%)$, root girth $(84.54 \%)$, stem girth $(84.15 \%)$, pod fresh weight $(78.21 \%)$, lamina width $(76.90 \%)$, petiole length $(74.60 \%)$, stem fresh weight (74.93\%), stem dry weight $(74.53 \%)$, root height (74.09\%), lamina length (72.10), and root branch $(72.17 \%)$. 


\section{Int.J.Curr.Microbiol.App.Sci (2017) 6(2): 424-429}

Table.1 Analysis of variance for different characters of Desmodium gangeticum(L.) DC

\begin{tabular}{|c|c|c|c|c|c|c|c|c|c|c|c|c|c|c|}
\hline \multicolumn{15}{|l|}{$\begin{array}{l}\text { Source of } \\
\text { variation }\end{array}$} \\
\hline Characters & D.F & $\begin{array}{l}\text { Plant } \\
\text { height } \\
(\mathrm{cm})\end{array}$ & $\begin{array}{c}\text { Tip } \\
\text { height } \\
(\mathrm{cm})\end{array}$ & $\begin{array}{l}\text { Stem } \\
\text { girth } \\
(\mathrm{mm})\end{array}$ & $\begin{array}{l}\text { Root } \\
\text { girth } \\
(\mathrm{mm})\end{array}$ & $\begin{array}{l}\text { Root } \\
\text { length } \\
(\mathrm{cm}) \\
\end{array}$ & $\begin{array}{c}\text { Root } \\
\text { branch }\end{array}$ & $\begin{array}{l}\text { Primary } \\
\text { Branch }\end{array}$ & $\begin{array}{l}\text { Secondary } \\
\text { Branch }\end{array}$ & $\begin{array}{c}\text { No of } \\
\text { Leaves }\end{array}$ & $\begin{array}{c}\text { No of } \\
\text { Inflorescence }\end{array}$ & $\begin{array}{r}\text { Le } \\
\text { Infl } \\
\end{array}$ & $\begin{array}{l}\text { th of } \\
\text { escenc }\end{array}$ & $\begin{array}{c}\text { Plant } \\
\text { weight }\end{array}$ \\
\hline Replication & 2 & 15.47 & 27.93 & 9.97 & 8.36 & 75.55 & 5.62 & 5.41 & 88.41 & 127447.68 & 27925.03 & & 23 & 149006.33 \\
\hline Germplasm & 29 & $\begin{array}{c}4641.58 \\
*\end{array}$ & 189.76 & $20.46^{*}$ & $5.81 *$ & $57.99 *$ & $81.85^{*}$ & $3.80 *$ & $11.17 *$ & $39581.36^{*}$ & $4684.71 *$ & & $15 *$ & $44834.42 *$ \\
\hline Error & 58 & 111.54 & 10.03 & 1.21 & 0.33 & 6.05 & 9.32 & 0.58 & 2.69 & 9274.65 & 2036.52 & & 01 & 8361.04 \\
\hline \multicolumn{15}{|l|}{ Source of } \\
\hline variation & & \multicolumn{13}{|c|}{ Mean sum of squares } \\
\hline Characters & D.F & $\begin{array}{c}\text { Root } \\
\text { fresh } \\
\text { weight }\end{array}$ & $\begin{array}{c}\text { Root } \\
\text { dry } \\
\text { weight }\end{array}$ & $\begin{array}{l}\text { Stem fresh } \\
\text { weight }\end{array}$ & & $\begin{array}{l}\text { Stem dry } \\
\text { weight }\end{array}$ & $\begin{array}{c}\text { Leaf fresh } \\
\text { weight }\end{array}$ & $\begin{array}{l}\text { Leaf dry } \\
\text { weight }\end{array}$ & $\begin{array}{l}\text { Leaf area } \\
\quad\left(\mathrm{cm}^{2}\right)\end{array}$ & $\begin{array}{l}\text { Pod fresh } \\
\text { weight }\end{array}$ & $\begin{array}{l}\text { Lamina } \\
\text { width }\end{array}$ & $\begin{array}{l}\text { Lamina } \\
\text { length }\end{array}$ & $\begin{array}{l}\text { Petiole } \\
\text { length }\end{array}$ & $\begin{array}{l}\text { Internode } \\
\text { length }\end{array}$ \\
\hline Replication & 2 & 78.76 & 8.19 & 24123.61 & & 5850.58 & 6897.58 & 1456.55 & 130.23 & 171.86 & 0.78 & 0.85 & 0.09 & 0.31 \\
\hline Germplasm & 29 & $330.65^{*}$ & $91.29 *$ & $19277.92 *$ & & $5037.98 *$ & $11037.49 *$ & $2554.37 *$ & $337.21 *$ & $471.09 *$ & 2.98 & $6.72 *$ & 0.58 & 1.21 \\
\hline Error & 58 & 66.79 & 13.47 & 1933.88 & & 515.08 & 1485.47 & 408.38 & 4.57 & 40.02 & 0.27 & 0.77 & 0.06 & 0.48 \\
\hline
\end{tabular}

${ }^{*} p<0.05$ 
Table.2 Estimates of genetic parameters; GCV, PCV, heritability and expected genetic advance

\begin{tabular}{llcccc}
\hline $\begin{array}{l}\text { Sr. } \\
\text { No. }\end{array}$ & Characters & GCV $(\%)$ & PCV $(\%)$ & $\begin{array}{c}\text { Heritability } \\
(\%)\end{array}$ & $\begin{array}{c}\text { Genetic advance } \\
(\%) \text { of mean }\end{array}$ \\
\hline 1 & Plant height & 30.44 & 31.55 & 93.12 & 11.16 \\
2 & Tip height & 50.12 & 54.16 & 85.65 & 14.03 \\
3 & Stem girth & 29.23 & 31.87 & 84.15 & 10.67 \\
4 & Root girth & 22.45 & 24.42 & 84.54 & 9.36 \\
5 & Root height & 17.14 & 19.91 & 74.09 & 7.91 \\
6 & Root branch & 33.58 & 39.53 & 72.17 & 11.00 \\
7 & Primary branch (PB) & 31.36 & 38.94 & 64.83 & 10.35 \\
8 & Secondary branch (SB) & 36.04 & 50.36 & 51.21 & 10.46 \\
9 & Number of leaves & 40.78 & 56.48 & 52.13 & 11.18 \\
10 & Number of inflorescence & 49.60 & 90.21 & 30.23 & 10.76 \\
11 & Length of inflorescence & 19.97 & 24.17 & 68.25 & 8.37 \\
12 & Plant weight & 48.90 & 63.53 & 59.25 & 12.64 \\
13 & Root fresh weight & 45.62 & 60.51 & 56.82 & 12.08 \\
14 & Root dry weight & 49.44 & 60.94 & 65.82 & 13.05 \\
15 & Stem fresh weight & 67.68 & 78.18 & 74.93 & 15.77 \\
16 & Stem dry weight & 66.92 & 77.52 & 74.53 & 15.66 \\
17 & Leaf fresh weight & 67.34 & 81.55 & 68.18 & 15.36 \\
18 & Leaf dry weight & 64.24 & 80.52 & 63.65 & 14.75 \\
19 & Leaf area & 29.48 & 30.08 & 96.03 & 11.07 \\
20 & Pod fresh weight & 70.24 & 79.42 & 78.21 & 16.24 \\
21 & Lamina width & 17.69 & 20.70 & 76.90 & 8.01 \\
22 & Lamina length & 17.12 & 20.16 & 72.10 & 7.85 \\
23 & Petiole length & 17.10 & 19.80 & 74.60 & 7.92 \\
24 & Internode length & 17.10 & 29.67 & 33.21 & 6.47 \\
\hline
\end{tabular}

The moderate heritability was exhibited by length of inflorescence $(68.25 \%)$, leaf fresh weight $(68.18 \%)$, root dry weight $(65.82 \%)$, primary branches $(64.83 \%)$, leaf dry weight $(63.65 \%)$ and plant weight $(59.25 \%)$. Low heritability was observed in internode length, secondary branches and number of leaves plant $^{-1}$.

\section{Expected genetic advance}

Expected genetic advance was estimated over mean and broad sense heritability. The range of genetic advance estimated was $6.47 \%$ for internode length to $16.24 \%$ for pod fresh weight. High genetic advance was recorded in stem fresh weight (15.77\%), stem dry weight (15.66\%), leaf fresh weight (15.36\%), leaf dry weight $(14.75 \%)$ and tip height $(14.03 \%)$. Moderate magnitude of genetic advance was observed in root dry weight $(13.05 \%)$, plant height $(12.64 \%)$, root fresh weight $(12.08 \%)$, number of leaves (11.18\%), plant height $(11.16 \%)$ and leaf area (11.07\%), lamina length root height, petiole length and root girth exhibited comparatively low expected genetic advance. High estimates of components of variances and heritability have also been reported in safflower for several yield contributing and quality traits by Reddy (2002) and Mahajan (2007). 
In conclusion, the analysis of different components of variability studies such as genotypic coefficient of variation (GCV), phenotypic coefficient of variation (PCV), heritability (broad sense) and expected genetic advance over mean indicated the existence of ample amount of variability in the germplasm lines of $D$. gangeticum (L.) DC. Thus, these germplasm lines could be utilized to improve root fresh weight, root dry weight and related characters in future breeding programme as roots are mainly used for the Ayurvedic formulations. Minimum differences were noted between the GCV and PCV values with high heritability estimates which clearly indicates little share of environmental component of variance. This suggests negligible influence of environment on the expression of these characters and hence, selection for yield could prove effective and improvement may be possible through recurrent selection programme.

\section{Acknowledgement}

Authors are thankful to the Director - Dr Satyabrata Maiti, Directorate of Medicinal and Aromatic Plants Research (DMAPR), Anand for providing the necessary research facilities.

\section{References}

Burton, G.W. 1952. Quantitative inheritance in grasses. Proc. 6th Int. Grassland Cong., 1: 277 - 283.

Chopra, R.N., Nayar, S.L. and Chopra, I.C.
1956. Glossary of Indian Medicinal Plants, CSIR, New Delhi, pp. 94.

Iwu, M.M., Jackson, J.E., Tally, J.D. and Klayman, D.L. 1992. Evaluation of plant extracts for antileishmanial activity using a mechanism based ratio respirometricmicro-technique (RAM). Plant media, 58: 436-441.

Kirtikar, K.R. and Basu, B.D. 1975. Indian Medicinal plants.Lalith Mohan Basu, Allahabad, India, pp. 758.

Kumar, M. and Shekhawat, S.S. 2013. Genetic variability in barley (Hordeumvulgare L.). Electron. J. Plant Breed., 4(4): 1309-1312.

Mahajan, P.V. 2007. Evaluation of progenies selected from random mated population of safflower using genetic male sterile lines. M.Sc. (Agri) Thesis. Dr.P.D.K.V. Akola.

Nadkarni, K.M. 1976. Hedysarum gangeticum (L). The Indian Materia Media, Popular Prakashan Pvt. Ltd., Bombay, 1: 612-613.

Reddy, N.S.H. 2002. Studies on recurrent selection in a safflower population segregating for genetic male sterility MSc thesis (unpublished) Dr. PDKV, Akola.

Sharma, R., Maloo, S.R., and Joshi, A. 2014. Genetic variability analysis in diverse maize genotypes (Zea mays L.). Electron. J. Plant Breed., 5(3): 545-551.

Singh, B.D. 2005. Population improvement. Plant Breeding: Principles and Methods. Kalyani Publishers, New Delhi. $7^{\text {th }}$ Ed. 367-395.

\section{How to cite this article:}

Nandanwar, H.R., P. Manivel, A.S. Patil, A.A. Punewar and Saravanan, R. 2017. Genetic Diversity Studies in Desmodium gangeticum (L.) DC. Int.J.Curr.Microbiol.App.Sci. 6(2): 424429. doi: http://dx.doi.org/10.20546/ijcmas.2017.602.047 